\section{Commentary: An arteriovenous bridge over novel, troubled water}

\author{
Serge Kobsa, MD, PhD, ${ }^{a}$ Nicholas J. Morrissey, MD, ${ }^{b}$ \\ and Hiroo Takayama, MD, $\mathrm{PhD}^{\mathrm{a}, \mathrm{c}, \mathrm{d}}$
}

It is estimated that more than 6 million Americans are living with heart failure (HF) and projected that this number will increase $46 \%$ from 2012 to 2030 , resulting in $>8$ million people with $\mathrm{HF}$ in the United States. ${ }^{1}$ Approximately 25,000 patients between 2006 and $2018^{2}$ have been supported by implanted mechanical circulatory devices, and one half of all heart transplant recipients are being bridged using mechanical circulatory support. ${ }^{3}$ Notably, a significant number of these patients are hemodialysis dependent. ${ }^{4}$ The high incidence of renal dysfunction in patients with end-stage HF is unsurprising, given that many of them have significant environmental and genetic cardiovascular risk factors and multiple comorbidities. ${ }^{5}$ In addition, they experience chronically inadequate renal perfusion secondary to long-standing HF, as well as being at risk for acuteon-chronic kidney injury during episodes of decompensated $\mathrm{HF}$, or during periods of hemodynamic instability related to MCS device implantation or other cardiac procedures.

Strategies for addressing vascular access in patients with continuous-flow left ventricular assist devices have been well described. ${ }^{6,7}$ Because of theoretical concerns regarding arteriovenous (AV) fistula venous maturation in the absence of pulsatile flow, ${ }^{6,7}$ we and many other experts opt to use $\mathrm{AV}$ grafts in patients with continuous-flow left ventricular assist devices. ${ }^{8}$ The authors pursued the creation of a staged brachiobasilic arteriovenous fistula in a patient supported with a total artificial heart (TAH). ${ }^{9}$ This approach appears plausible for a number of reasons. The Syncardia TAH

\footnotetext{
From the Divisions of a Cardiac and Thoracic Surgery and ${ }^{b}$ Vascular Surgery, ${ }^{\mathrm{c}}$ Cardiovascular Institute, and ${ }^{\mathrm{d}}$ Aortic Center, Columbia University Medical Center, New York, NY.

Disclosures: The authors reported no conflicts of interest.

The Journal policy requires editors and reviewers to disclose conflicts of interest and to decline handling or reviewing manuscripts for which they may have a conflict of interest. The editors and reviewers of this article have no conflicts of interest.

Received for publication July 7, 2020; revisions received July 7, 2020; accepted for publication July 14, 2020; available ahead of print July 21, 2020.

Address for reprints: Hiroo Takayama, MD, PhD, Columbia University Medical Center, Milstein Hospital Building, 177 Fort Washington Ave, Suite 7-435, New York, NY 10032 (E-mail: ht2225@cumc.columbia.edu).

JTCVS Techniques 2020;3:223-4

2666-2507

Copyright ( $\subset 2020$ The Authors. Published by Elsevier Inc. on behalf of The American Association for Thoracic Surgery. This is an open access article under the CC BY-NCND license (http://creativecommons.org/licenses/by-nc-nd/4.0/).

https://doi.org/10.1016/j.xjtc.2020.07.014
}

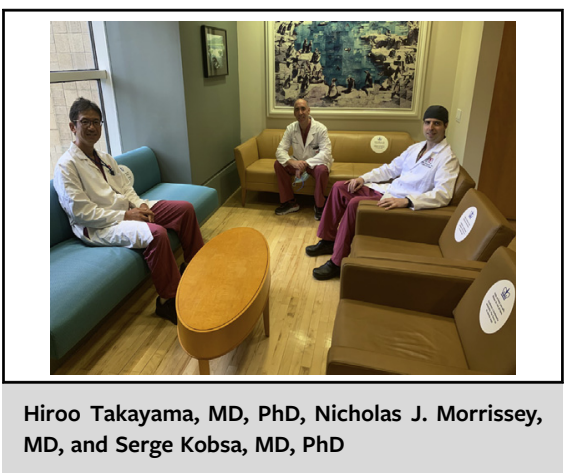

CENTRAL MESSAGE

An arteriovenous fistula presents a viable permanent dialysis access in a patient with a total artificial heart.

(SynCardia Systems, Inc, Tucson, Ariz), the only TAH approved by the Food and Drug Administration in the United States, ${ }^{10}$ is a pneumatically driven pulsatile flow device, which mitigated the concern for lack of AVF maturation. Use of a native vein may reduce another concern in patients with an implanted MCS device, which is infection and hematogenous seeding of the implant. This risk is augmented by repeated vascular access necessary for hemodialysis, and particularly exacerbated by the presence of an indwelling tunneled dialysis catheter. The use of a dialysis catheter with TAH requires extra caution due to the presence of a mechanical tricuspid valve as well. Furthermore, an AV graft might increase the risk of local infection after a heart (and kidney) transplant.

The authors acknowledge uncertainty regarding the potential for TAH-driven super-physiologic pulsatile flow affecting fistula arterialization and wall integrity but report that the AVF did adequately mature, with sufficient size, arterialization, wall thickening, and high flow rates, despite requiring 3 interventions for atypical aneurysmal degeneration of the arterial limb of the fistula during the 15 months of use, before the patient received a heart-kidney transplant. With more experience, the procedure may be performed in a single setting, saving the patient a second operation.

Like in most cases of advances borne out of necessity, Hair and colleagues used their judgment and experience and applied sound surgical principles to a novel clinical scenario while dealing with uncertainty. Despite complications, their team managed to successfully bridge a patient to a double-organ transplant and demonstrate that, especially as medical devices 
and technology become ever more complex and ubiquitous, surgeons will continue to innovate.

\section{References}

1. Virani SS, Alonso A, Benjamin EJ, Bittencourt MS, Callaway CW, Carson AP, et al. Heart disease and stroke statistics - 2020 update: a report from the American Heart Association. Circulation. 2020;141:e139-596.

2. Teuteberg JJ, Cleveland JC, Cowger J, Higgins RS, Goldstein DJ, Keebler M, et al. The Society of Thoracic Surgeons intermacs 2019 annual report: the changing landscape of devices and indications. Ann Thorac Surg. 2020;109: 649-60.

3. Khush KK, Cherikh WS, Chambers DC, Harhay MO, Hayes D Jr, Hsich E, et al. The international thoracic organ transplant registry of the International Society for Heart and Lung Transplantation: thirty-sixth adult heart transplantation report-2019; focus theme: donor and recipient size match. J Heart Lung Transplant. 2019;38:1056-66.
4. Kamboj M, Kazory A. Left ventricular assist device and the kidney: getting to the heart of the matter. Blood Purif. 2019;48:289-98.

5. Ross DW, Stevens GR, Wanchoo R, Majure DT, Jauhar S, Fernandez HA, et al. Left ventricular assist devices and the kidney. Clin J Am Soc Nephrol. 2018;13:348-55.

6. Amir O, Radovancevic B, Delgado RM, Kar B, Radovancevic R, Henderson M, et al. Peripheral vascular reactivity in patients with pulsatile vs axial flow left ventricular assist device support. J Heart Lung Transplant. 2006;25:391-4.

7. Patel AM, Adeseun GA, Ahmed I, Mitter N, Rame JE, Rudnick MR. Renal failure in patients with left ventricular assist devices. Clin J Am Soc Nephrol. 2013;8: 484-96.

8. Allon M, Lok CE. Dialysis fistula or graft: the role for randomized clinical trials. Clin J Am Soc Nephrol. 2010;5:2348-54.

9. Hair BB, Kirksey L, Tong MZ, Soltesz E, Hanna M. Permanent dialysis access in a patient with a total artificial heart. J Thorac Cardiovasc Surg Tech. 2020;3: 220-2.

10. Melton N, Soleimani B, Dowling R. Current role of the total artificial heart in the management of advanced heart failure. Curr Cardiol Rep. 2019;21:142. 